\title{
Influence of storage mode and duration on the microscopic enumeration of Synechococcus from a cold coastal ocean environment
}

\author{
Jennifer N. Putland, Richard B. Rivkin* \\ Ocean Sciences Centre, Memorial University of Newfoundland, St. John's, Newfoundland A1C 5S7, Canada
}

\begin{abstract}
Photosynthetic picoplankton of the genus Synechococcus can represent a substantial proportion of planktonic community biomass and production in many oceanic provinces. These cells are typically enumerated by visualizing the autofluorescence of phycoerythrin using epifluorescence microscopy. Detailed studies of bacterioplankton and preliminary studies with photosynthetic pico- and nanoplankton suggest that the number of cells which can be visualized changes with mode and duration of sample storage. Inaccurate estimates of Synechococcus abundance may bias the interpretation of the distribution and turnover of microbial stocks. We carried out a comprehensive, long-term ( $\sim 0.9 \mathrm{yr})$ time-course study to determine if storage mode and duration influence microscopic estimates of Synechococcus abundance. Seawater samples preserved with gluteraldehyde were either stored at $4^{\circ} \mathrm{C}$ until counting (i.e. RS-refrigerated in suspension) or slides were prepared and stored at $-20^{\circ} \mathrm{C}$ until counting (i.e. FF-filtered and frozen). Over time, both methods converged on an apparent cell loss (ACL; i.e. loss of epifluorescence-detectable cells) of ca $45 \%$. Significant ( $\leq 50.05$ ) ACL occurred within 1 mo for the RS method, whereas cell numbers were unchanged for the first 2 mo for the FF method. Apparent cell loss was hyperbolic for both storage modes and the rate constants for decay were similar. Our results are consistent with the suggestion in the literature that ACL may have been due to persistence of intracellular autolytic enzymes in the preserved cells. We also examined the influence of the excitation wavebands on the estimation of Synechococcus abundances. About twice as many Synechococcus were observed using green (490 to $545 \mathrm{~nm}$ ) compared to blue (450 to $490 \mathrm{~nm}$ ) excitation epifluorescence microscopy and this increase was significant $(p<0.001)$. Based on our results, we recommend that samples for the enumeration of Synechococcus be immediately preserved, filtered, frozen, and counted using green excitation within 2 mo.
\end{abstract}

KEY WORDS: Apparent cell loss - Epifluorescence microscopy $\cdot$ Microbial food webs - Sample storage . Synechococcus

\section{INTRODUCTION}

Photosynthetic picoplankton (i.e. autotrophs 0.2 to $2 \mu \mathrm{m}$ in diameter) are an important component of marine (Joint 1986, Fenchel 1988, Stockner 1988) and freshwater (Caron et al. 1985, Fahnenstiel \& Carrick 1991, Nagata et al. 1994) ecosystems. Like heterotrophic bacteria (Fuhrman et al. 1989, Cho \& Azam 1990, Li et al. 1992), photosynthetic picoplankton can

\footnotetext{
- Addressee for correspondence.

E-mail: rrivkin@morgan.ucs.mun.ca
}

represent a substantial proportion of community biomass and production (e.g. up to $80 \%$ of phytoplankton biomass and production; Li et al. 1983, Platt et al. 1983, Herbland et al. 1985, Nagata et al. 1994, Magazzù \& Decembrini 1995). Chroococcoid cyanobacteria belonging to the genus Synechococcus are a dominant constituent of photosynthetic picoplankton (Stockner \& Antia 1986, Stockner 1988). Photosynthetic picoplankton are generally observed using epifluorescence microscopy (Caron et al. 1985, Booth 1988, Glover et al. 1988, Fuhrman et al. 1989) and Synechococcus is distinguished from eucaryotic picoplankton based upon the autofluorescence of its accessory pigment, 
phycoerythrin. Inaccurate estimates of Synechococcus abundance may bias the interpretation of the distribution and turnover of microbial stocks. Moreover, predictive models, which derive flows from stock estimates (e.g. inverse modelling; Vézina \& Platt 1988, Jackson \& Eldridge 1992), can be highly sensitive to systematic error in the estimate of biomass. Several of the factors which can lead to inaccurate estimates of Synechococcus abundance include environmental heterogeneity, sample storage and duration, type and concentration of preservative used to fix the sample, cell identification, and counting precision (Hasle 1978, Throndsen 1978, Venrick 1978a, b, Hall 1991). This study examines the influence of the mode and duration of storage on the enumeration of the procaryotic picoplankton Synechococcus.

Samples collected at sea for the enumeration of Synechococcus ideally should be preserved, filtered, and counted immediately (Booth 1987, 1988, Hall 1991). However, time constraints and sea conditions often preclude either filtering or counting samples on board. Hence, preserved samples are either filtered and frozen ( $F F$ method) or refrigerated in suspension (RS method) until slides can be prepared and counted on shore days, weeks, even years after collection. Recent studies for bacteria show that the storage mode and duration may significantly diminish the ability to visualize fluorochrome-stained cells. For example, RSstored bacteria showed a substantial (31 to $46 \%$ ) apparent cell loss $(\mathrm{ACL}$; reduction in epifluorescencedetectable cells) within $40 \mathrm{~d}$ of sample collection. In contrast, FF-stored bacteria showed negligible ACL within $70 \mathrm{~d}$ of sample collection (Turley \& Hughes 1992, 1994, Turley 1993, Troussellier et al. 1995, Gundersen et al. 1996). There are fewer studies on the effect of storage on the ACL of Synechococcus. Hall (1991) showed that there was no ACL for $\sim 105 \mathrm{~d}$ when eucaryotic picoplankton were preserved in paraformaldehyde and slides stored at -20 or $-70^{\circ} \mathrm{C}$. Although this author implied that there was little loss of phycoerythrin autofluorescence when procaryotic picoplankton were preserved in glutaraldehyde and slides stored at $-20^{\circ} \mathrm{C}$, this effect was not quantified. Booth (1987) reported no significant ACL for up to $2 \mathrm{yr}$ for Syncchococcus collected in the suharctic. Pacific. preserved with glutaraldehyde and slides stored at $-20^{\circ} \mathrm{C}$. However a reexamination of Booth's data (Booth 1987; Table III) shows the large coefficient of variation $(\mathrm{CV})$ for both the initial (mean $=26 \%$, range = 15 to $44 \%$ ) and final (mean $=41 \%$, range $=25$ to $60 \%$ ) counts may have obscured detection of a significant ACL.

This study was specifically designed to quantify the effects of both storage mode and duration on the $A C L$, and hence abundance estimates, of Synechococcus.
We carried out a comprehensive, $\sim 1$ yr time-course study comparing the RS and FF methods of storing Synechococcus. Our results show that the FF method is effective at preventing ACL for ca 2 mo. However, both storage modes result in the same ACL (ca $45 \%$ ) after $4 \mathrm{mo}$.

\section{MATERIALS AND METHODS}

Time-course experiment. Seawater collected on 12 October 1995 at a depth of $5 \mathrm{~m}$ from Logy Bay, Newfoundland, Eastern Canada $\left(47^{\circ} 38^{\prime} 14^{\prime \prime} \mathrm{N}, 52^{\circ} 39^{\prime}\right.$ $36^{\prime \prime}$ W) using a PVC Niskin bottle was immediately transferred into a darkened polycarbonate carboy. Within an hour of collection, 41 of the seawater was transferred into a polycarbonate bottle and preserved with glutaraldehyde ( $1.5 \%$ final concentration). After a 20 min fixation period (Booth 1987, Macisaac \& Stockner 1993), eighteen $50 \mathrm{ml}$ samples were collected onto $0.4 \mu \mathrm{m}$ polycarbonate filters and immediately counted and stored at $-20^{\circ} \mathrm{C}$ (see details below). The remaining 21 of preserved seawater was stored in darkness at $4^{\circ} \mathrm{C}$ in a 21 polycarbonate bottle. All sample handling and slide preparation was carried out in subdued light.

Initially $(\mathrm{n}=18)$ and at about 30 to $60 \mathrm{~d}$ intervals for $315 \mathrm{~d}$ ( $\mathrm{n}=4$ at each time point), Synechococcus was counted from a subset of the slides prepared and frozen on 12 October 1995. We refer to the samples counted from Days -30 to 315 as the 'filtered and frozen' (FF) storage method. A second set of slides ( $\mathrm{n}=$ 4 at each time point) were prepared from the preserved seawater on the date of collection and initial counting. We refer to these samples as the 'refrigerated in suspension' (RS) storage method.

Samples for epifluorescent enumeration of Synechococcus were prepared following the method of Booth (1987). Preserved seawater $(50 \mathrm{ml})$ was gently filtered (under low vacuum; $<127 \mathrm{~mm} \mathrm{Hg}$ ) onto $25 \mathrm{~mm}$ prestained black $0.4 \mu \mathrm{m}$ Poretics filters until the filters were just dry. The filters were mounted onto a glass slide over a drop of Cargille Type A immersion oil. A second drop of oil was placed on the filter and a glass cover slip was placed on top of that. Gentle pressure was applied to the cover slip to evenly distribute the oil.

Cells were counted using a $\mathrm{BH} 2-\mathrm{RFC}$ Olympus epifluorescence microscope equipped with a $100 \mathrm{~W}$ mercury lamp (HBO $100 \mathrm{~W}$ ) and configured for green excitation (BP545, DM570, O590). This filter combination resulted in a wide excitation waveband 4990 to $545 \mathrm{~nm}$ ). Synechococcus was counted using a $60 \times$ objective (S Plan Apo 60,1.40), a $1.25 \times$ column magnifier, and $10 \times$ WHK eyepiece. Cells were identified as $\sim 1 \mu \mathrm{m}$ in diameter fluorescing yellow-orange coccoid 
cells. During enumeration, the field diaphragm was partially closed so as to minimize quenching and maximize image contrast. For each filter, 10 random fields were viewed (Kirchman 1993), which resulted in a total count of 200 to 400 cells per filter. To avoid recounting areas of the filter, cells were counted on sequential, non overlapping transects. Each field of view was $0.008 \mathrm{~mm}^{2}$ and a total of $0.07 \%$ of each filter was enumerated.

Comparison of blue excitation (Zeiss) and green excitation (Olympus) to enumerate Synechococcus. The waveband used to excite phycoerythrin may also influence the detection of cells and hence the abundance estimate. To evaluate this effect, we compared Synechococcus counts using blue (Zeiss) and green excitation (Olympus). On 24 July 1996, we recounted the 18 filters that were prepared on 12 October 1995 using a Zeiss Axiovert and an Olympus epifluorescence microscope. The Zeiss Axiovert was equipped with a $50 \mathrm{~W}$ mercury lamp and configured with the standard filter combination for blue excitation (filter set 487709 , reflector 510, excitation 450 to $490 \mathrm{~nm}$, barrier filter 520). Synechococcus were counted using a $63 \times$ oil immersion objective (Plan Apo 63, 1.40) and 10x eyepieces (PI 10X/25) and cells were visualized as ca $1 \mu \mathrm{m}$ diameter yellow autofluorescing coccoids. The Olympus BH2-RFC was equipped as described above. The same counting procedures were used with both epifluorescence microscopes.

\section{RESULTS}

\section{Time-course}

Apparent change in the abundance of Synechococcus over the 10.5 mo of the study for the FF and RS methods is shown in Fig. 1. For the FF method, Synechococcus abundance was not statistically different for the first $54 \mathrm{~d}$ (Student-Newman-Keuls [SNK] test, $p>0.05)$. Counts from Days 105 to 315 were also not significantly different (SNK test, $p>0.05$ ), but were significantly lower than counts made on Days 0 to 54 (SNK test, $p<0.05$ ). For the RS method, Synechococcus abundances were significantly lower on Days 34 to 315 than on Day 0 when the seawater was collected (SNK test, $\mathrm{p}<0.05$ ). The counts made from Days 34 to 315 were not significantly different (SNK test, $\mathrm{p}>0.05$ ).

The decline (after Days 0 and 54 for the RS and FF methods, respectively) in Synechococcus counts (i.e.
ACL) was hyperbolic and described by the following equation:

$$
y=(a \times b) /(b+x)
$$

where $y=$ Synechococcus count (cells $\mathrm{l}^{-1}$ ) at time $x$ (days), and $a$ and $b$ ( \pm standard error) are constants. For the FF method, $a=1.906 \times 10^{7}\left( \pm 1.795 \times 10^{6}\right), b=$ $2.668 \times 10^{2}( \pm 68.35)$, and $r^{2}=0.87$. For the RS method, $a=1.683 \times 10^{7}\left( \pm 1.472 \times 10^{6}\right), b=2.803 \times 10^{2}( \pm 86.88)$, and $r^{2}=0.71$. The coefficients $a$ and $b$ did not significantly differ for the 2 storage modes.

We compared the initial abundances of Synechococcus (on 12 October 1995) with those on Days 34 to 315 for the RS method and Days 105 to 315 for the FF method. In the case of the FF method, the Days 105 to 315 interval was used since Synechococcus abundances were constant for the first $54 \mathrm{~d}$ (Fig. 1) of the time-course. The average abundances of Synechococcus after Days 34 and 105 for the RS and FF methods, respectively, were 53 to $55 \%$ of the initial counts (Table 1). This represents an ACL of 45 to $47 \%$ (i.e. reduction in the number of Synechococcus cells that were initially detected on Day 0). Furthermore, the thawing and refreezing of the slide used for the FF method was not responsible for the ACL observed for this storage mode. We compared Synechococcus abundances for slides which had been kept frozen for 10 mo with those that were thawed and refrozen 7 times over the same 10 mo period. The abundance of Synechococcus and the CV of the count were not significantly different ( $t$-test; $t=1.39, \mathrm{p}=0.18)$ for the 2 treatments. The average CV of counts for the RS method and initial counts were similar ( 20 to $23 \%$ ) whereas the CV was higher $(30 \%)$ for the FF method. Since the 
Table 1. Descriptive statistics for Synechococcus $\left(10^{6}\right.$ cells $\left.l^{-1}\right)$ counted on 12 October 1995 (initial) and for samples stored frozen on filters (FF) and refrigerated in suspension (RS) and subsampled at 30 to $60 \mathrm{~d}$ intervals for $315 \mathrm{~d}$. CV: coefficient of variation; n: number of filters counted

\begin{tabular}{|lccc|}
\hline Statistic & Initial & $\begin{array}{c}\text { FF } \\
\text { Days 105 to 315 }\end{array}$ & $\begin{array}{c}\text { RS } \\
\text { Days 34 to 315 }\end{array}$ \\
& \multicolumn{3}{c}{} \\
Maximum & 22.6 & 12.7 & 11.9 \\
Minimum & 15.2 & 8.3 & 8.8 \\
Median & 19.5 & 10.8 & 10.1 \\
Mean & 19.4 & 10.6 & 10.2 \\
CV & 20 & 30 & 23 \\
n & 18 & 24 & 32 \\
\hline
\end{tabular}

average abundance of Synechococcus was the same for the RS and FF methods (Table 1), the higher CV was not due to a density dependent decrease in the precision of counting.

The precision of the Synechococcus cell counts decreased with increasing storage time for both the FF and RS methods (Fig. 2). The increase in CV over time was linear and the slopes were significantly $(\mathrm{p}<0.05)$ different from zero. For the FF method:

$C V=21.0( \pm 2.0)+0.04( \pm 0.01) \times$ days $; r^{2}=0.72, p<0.01$ and for the RS method:

$C V=12.5( \pm 2.6)+0.06( \pm 0.01) \times$ days $; r^{2}=0.73, p<0.01$

The implicit null hypothesis that storage mode and duration do not affect Synechococcus abundance estimates was not supported. The initial, FF, and RS counts were significantly different (Kruskal-Wallis ANOVA; $H=37.6, \mathrm{p}<0.0001$ ). Moreover, a Dunn's Multiple
Table 2. Descriptive statistics of Synechococcus counts $\left(10^{6}\right.$ cells $\mathrm{l}^{-1}$ ) using blue excitation (Zeiss) and green excitation (Olympus) epifluorescence microscopes ( $n=18$ ). SD: standard deviation; CV: coefficient of variation

\begin{tabular}{lcc|}
\hline Statistic & Zeiss & Olympus \\
\hline Maximum & 9.9 & 17.7 \\
Minimum & 1.6 & 1.9 \\
Median & 4.4 & 10.7 \\
Mean & 5.2 & 11.2 \\
SD & 2.7 & 4.2 \\
CV & 52 & 38 \\
\hline
\end{tabular}

Comparison Test indicated that after Day 105, counts from the FF and RS methods were not significantly ( $p>$ $0.05)$ different from each other, but were significantly $(p<0.05)$ different from initial counts.

\section{Comparison of Synechococcus counts for blue and green excitation}

Epifluorescence microscopes with different excitation wavebands are commonly used to enumerate Synechococcus. As a subsidiary objective of this study, we evaluated if differences in excitation wavebands can influence the estimation of Synechococcus abundances. On 24 July 1996, we recounted the 18 frozen filters that were prepared on 12 October 1995 using both a Zeiss Axiovert equipped with blue excitation and an Olympus BH2-RFC equipped with green excitation (Table 2). Significantly more (ANOVA; $F=25.5$, $\mathrm{p}<0.001)$ Synechococcus were detected using the green than blue excitation (Fig. 3). The maximum, median, and mean for the counts made using blue excitation with the Zeiss were about half of those made using green excitation with the Olympus.

\section{DISCUSSION}

During long-term ( $>3$ to $4 \mathrm{mo}$ ) storage, both the FF and RS storage modes resulted in the same total ACL; however visible Synechococcus were lost at different rates. In samples stored for $\sim 4$ mo using the FF mode or $\sim 2$ mo using the RS mode, the ACL was $-45 \%$ (i.e. $55 \%$ of the Synechococcus cells initially detected were still visible). Previous studies on eucaryotic or procaryotic picoplankton (Vaulot et al. 1989, Hall 1991) reported similar patterns in ACL. The absolute loss rates of visible
Fig. 2. Synechococcus. Mean $( \pm S D$ ) coefficient of variation of counts as a function of storage time for samples stored frozen at $-20^{\circ} \mathrm{C}$ on filters (FF method) and refrigerated at $4^{\circ} \mathrm{C}$ in suspension (RS method) 

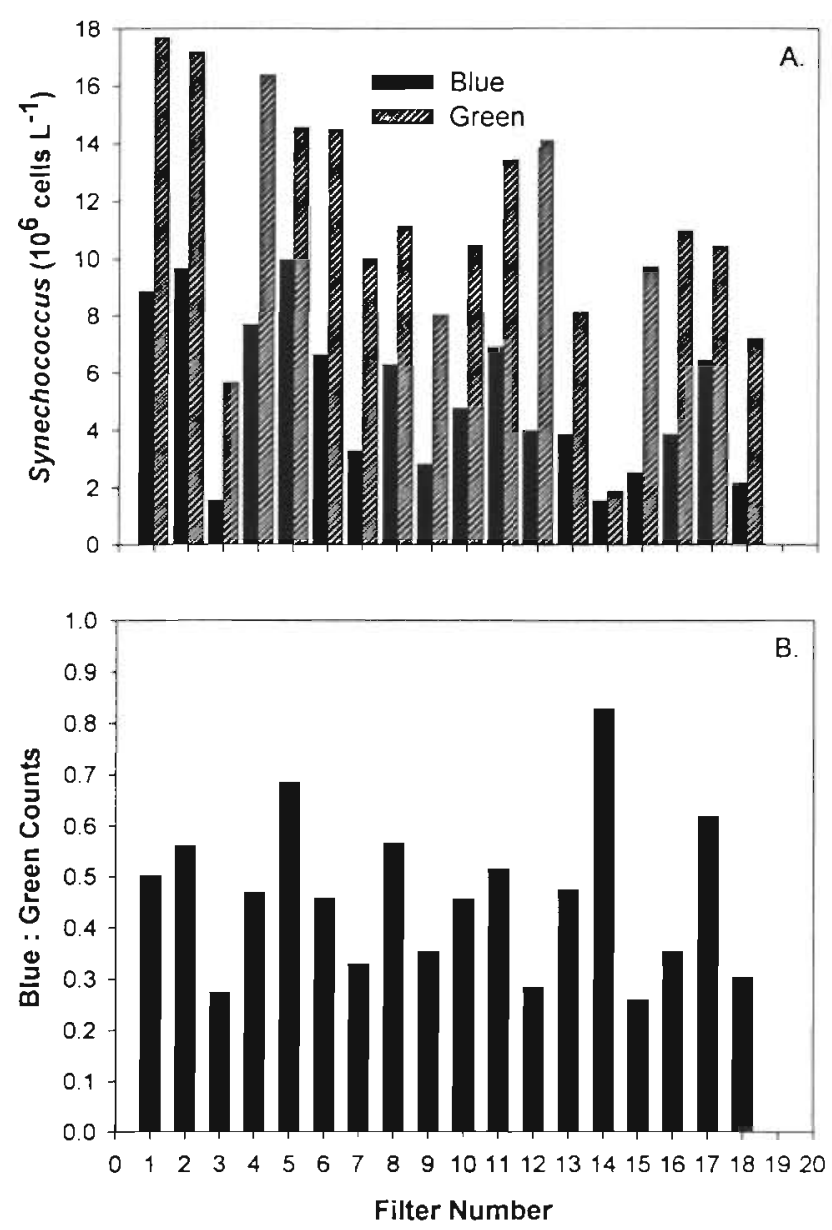

Fig. 3. Synechococcus (A) abundances and (B) ratio of abundance made with blue and green excitation on 18 replicate slides. The mean $( \pm \mathrm{SD})$ of the blue and green ratio was $0.46 \pm$ $0.15, \mathrm{n}=18$

cells varied over a period of weeks to months and this variability may have been due to the type of preservative used to fix the sample or the storage temperature. More extensive studies have been done for heterotrophic bacteria than photosynthetic picoplankton. Turley \& Hughes (1992) and Troussellier et al. (1995) did not observe significant differences in bacterial counts made at time of collection and for those made 70 to $112 \mathrm{~d}$ afterwards when stored using the FF method. In contrast, Turley \& Hughes (1992, 1994), Troussellier et al. (1995), and Gundersen et al. (1996) reported a 24 to $50 \%$ ACL of bacteria $40 \mathrm{~d}$ after seawater collection when samples were stored using the RS method. Studies with various other taxa of nanoand net phytoplankton have also reported that the FF method is more effective at preventing short-term ACL (Landry et al. 1984, Booth 1987). The similarity in the trends observed for our results and those reported for the same and different taxa suggests that ACL is a general phenomenon and that there may be a common cause for ACL.

What causes ACL and why does ACL occur at different rates for the FF and RS methods? Factors such as viral lysis, adhesion of cells to bottle walls, cell aggregation, and cell shrinkage have been proposed as contributing to ACL (Turley \& Hughes 1992, 1994, Gundersen et al. 1996); however, no single factor or combination of factors have been shown to account for the ACL in preserved samples (Turley \& Hughes 1992 and Gundersen et al. 1996). Turley \& Hughes (1994) found that the ACL of bacteria was greater when glutaraldehyde preserved samples were stored at higher (17 to 22 vs $6^{\circ} \mathrm{C}$ ) temperatures. More recently, Gundersen et al. (1996) suggested that residual autolytic enzyme activity in bacteria preserved with glutaraldehyde was a major cause for the ACL and that $\mathrm{ACL}$ should be greater at higher storage temperatures (Hoar 1983). The higher rate of ACL for the RS method (i.e. by Day 34 at $4^{\circ} \mathrm{C}$ ) relative to the FF method (i.e. by Day 105 at $-20^{\circ} \mathrm{C}$ ) is consistent with the mechanism proposed by Gundersen et al. (1996). Although the storage temperature was higher in the RS than the FF mode, there are other factors (e.g. quantity of free liquid surrounding the cells, the type of suspending medium, etc.) besides temperature which may have contributed to the more rapid ACL for the RS mode of storage.

We did not test for the effect of different fixatives; however other studies show similar trends albeit different ACL for autotrophic and heterotrophic picoplankton preserved with formalin or paraformaldehyde (Hall 1991, Turley \& Hughes 1992, Troussellier et al. 1995). Troussellier et al. (1995) and Hall (1991) reported that cell counts of bacteria and Synechococcus, respectively, were higher in samples preserved with paraformaldehyde than with glutaraldehyde. Since paraformaldehyde is more reactive than glutaraldehyde (Fessenden \& Fessenden 1986), the enzyme activity and hence ACL may have been lower in the paraformaldehyde preserved seawater.

About twice as many Synechococcus were observed using green excitation (i.e. Olympus) compared to blue excitation (i.e. Zeiss) epifluorescence microscopy (Table 2). The differences in the detection of Synechococcus may be attributed to the different excitation wavebands of the Olympus (490 to $545 \mathrm{~nm}$ ) and Zeiss ( 450 to $490 \mathrm{~nm}$ ) microscopes, the pigment composition of Synechococcus, or the lamp power supply (Olympus $=100 \mathrm{~W}$; Zeiss $=50 \mathrm{~W}$ ). Marine Synechococcus contain type I or II phycoerythrin (Wood et al. 1985). Type I phycoerythrin is composed of phycourobilin (excites at 490 to $500 \mathrm{~nm}$ ) and phycoerythrobilin (excites at 540 to $565 \mathrm{~nm}$ ) chromophores, whereas type II phycoerythrin is only composed of the phycoerythro- 
bilin chromophore (Maclsaac \& Stockner 1993). By using blue excitation (waveband 450 to $500 \mathrm{~nm}$ ), chlorophyll $a$ and type I phycoerythrin containing cells can be simultaneously enumerated (Waterbury et al. 1979, Booth 1988, Miyazono et al. 1992, Booth et al. 1993, Maclsaac \& Stockner 1993). This waveband is suitable for enumerating type I pigment-containing Synechococcus which generally predominate in clear oceanic habitats (Booth 1987, Campbell \& Iturriaga 1988, Li \& Wood 1988, Olson et al. 1988). However, the 450 to $490 \mathrm{~nm}$ waveband excitation of the Zeiss will not efficiently excite the type II pigment-containing Synechococcus; hence their abundances may be underestimated. Type II strains of Synechococcus generally pre- dominate in near-shore waters (Wood et al. 1985 , 1998). The broad excitation waveband of the Olympus microscope would facilitate the enumeration of both type I and II strains of Synechococcus in our samples. We infer from our results that a large fraction of the Synechococcus population in Logy Bay were type II phycoerythrin-containing cells, at least when samples were collected during October 1995.

Logy Bay is a coastal site with both low phytoplank-

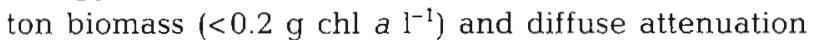
coefficients ( 0.08 to $0.1 \mathrm{~m}^{-1}$ ) during autumn (Crocker 1994, Rivkin unpubl.). However, because of its nearshore location and terrigenous and fluvial inputs, the surface waters would have a type 1 to 3 optical classifi-

Table 3. Studies reporting storage mode, duration of storage (i.e. time between sample collection and counting), excitation waveband and lamp power supply (W) used by various studies to enumerate Symechococcus in various marine environments. FF: filtered and frozen; RS: refrigerated in suspension; RF: refrigerated filters; FS: frozen in suspension; GJ: glycerine jelly mount; DNR: not reported

\begin{tabular}{|c|c|c|c|c|c|}
\hline Location & Storage mode & Storage time & Excitation & Power (W) & Source \\
\hline Chesapeake Bay & RS & DNR & Blue & 100 & Affronti \& Marshall (1993) \\
\hline NE Pacific & FF & $\leq 2 \mathrm{mo}$ & Blue and green & 50 & Booth (1987) \\
\hline NE Pacific & FF & $3 \mathrm{mo}$ & Blue & 50 & Booth (1988) \\
\hline NE Pacific & FF & $\leq 1 \mathrm{yr}$ & Blue & 50 & Booth et al. (1993) \\
\hline NW Indian & FF & Immediately & Green & 100 & Burkill et al. (1993) \\
\hline NW Atlantic & RS & $2 w k$ & Blue & 100 & Campbell \& Carpenter (1986) \\
\hline Vineyard Sound & FF & Immediately & Blue & 100 & Caron et al. (1991) \\
\hline Taiwan coast & FF & Immediately & Blue & 100 & Chang et al. (1996) \\
\hline Southern Ocean & FF & $2-3 \mathrm{mo}$ & Blue & DNR & Detmer \& Bathmann (1997) \\
\hline Sargasso Sea & FF & DNR & Blue & 100 & Fuhrman et al. (1989) \\
\hline NW Atlantic & FF & Immediately & Blue and green & 100 & Glover et al. (1986) \\
\hline Sargasso Sea & $\mathrm{FF}$ & Immediately & Blue and green & 100 & Glover et al. (1988) \\
\hline New Zealand coast & GJ & $<6 \mathrm{mo}$ & Green & 50 & Hall \& Vincent (1990) \\
\hline Himatangi Beach & FF & Variable & Green & 50 & Hall (1991) \\
\hline Southampton estuary & $\mathrm{FF}$ & $24-30 h$ & DNR & DNR & Iriarte \& Purdie (1994) \\
\hline Skagerrak & FS & $\leq 5 \mathrm{mo}$ & Blue & 50 & Karlson \& Nilsson (1991) \\
\hline Gulf of Finland & FF & Immediately & Green & 50 & Kononen et al. (1996) \\
\hline California coast & $\mathrm{FF}$ & $\leq 24 h$ & Blue & 100 & Krempin \& Sullivan (1981) \\
\hline Baltic Sea & FF & $6 \mathrm{~h}$ & Blue & 50 & Kuosa (1991) \\
\hline Skagerrak & $\mathrm{FF}$ & $\leq 24 h$ & Blue & 50 & Kuylenstierna \& Karlson (1994) \\
\hline Kaneohe Bay & FF & 1 wk & Blue & 50 & Landry et al. (1984) \\
\hline Tropical Pacific & $\mathrm{FF}$ & Immediately & Blue & 100 & Li et al. (1983) \\
\hline N. Atlantic & $\mathrm{RF}$ & Immediately & Green & 100 & Li \& Dickie (1991) \\
\hline N. Atlantic & $\mathrm{RF}$ & Immediately & Blue and green & 50 & Li \& Wood (1988) \\
\hline Australia and Antarctica & FF & Immediately & Green & 50 & Marchant et al. (1987) \\
\hline Mediterranean Sea & FF & Immediately & Blue & 100 & Maugeri et al. (1992) \\
\hline Iwanai Bay & FF & Immediately & Blue & 50 & Miyazono et al (1992) \\
\hline Scotian Shclf & $\mathrm{FF}$ & $1 \mathrm{~m} n$ & Blise & 50 & Mousseau et al. (1996) \\
\hline N. Atlantic & FF & Immediately & Blue and green & 50 & Murphy \& Haugen (1985) \\
\hline Mid-Atlantic & $\mathrm{FF}$ & Immediately & Blue & 100 & Platt et al. (1983) \\
\hline NW Allantic & $\mathrm{FF}$ & Immediately & Blue & 100 & Prezelin et a]. (1987) \\
\hline York River & DNR & DNR & Green & 50 & Ray et al. (1989) \\
\hline Boothbay Harbor & FF & Immediately & Blue and green. & 50 & Shapiro \& Haugen (1988) \\
\hline Bay of Villefranche & $\mathrm{FF}$ & $1-2 h$ & Blue & 50 & Sheldon et al. (1992) \\
\hline Western Pacific & RF & $\leq 4 \mathrm{~d}$ & Green & DNR & Shimada et al. (1993) \\
\hline Danish coast & $\mathrm{FF}$ & $1 \mathrm{mo}$ & Blue and green & 100 & Søndergaard et al. (1991) \\
\hline Northern Adriatic & FF & Immediately & Blue & 100 & Vanucci et al. (1994) \\
\hline Antarctica & FF & $>3 \mathrm{mo}$ & Blue & 50 & Walker \& Marchant (1989) \\
\hline Various regions & FF & Immediately & Blue & 100 & Waterbury et al (1979) \\
\hline
\end{tabular}


cation (Jerlov 1976, Kirk 1994) with high attenuation of blue light (i.e. $<450 \mathrm{~nm}$ ). Based upon the chromatic adaptation theory (Kirk 1994), type II phycoerythrincontaining Synechococcus should be favored in this environment, where green light predominates (Olson et al. 1988, Wood et al. 1998) and type I phycoerythrincontaining cells should be favored in clearer oceanic waters where blue light predominates. The observed large contribution of type II phycoerythrin containing cells to the total Synechococcus population in Logy Bay is consistent with this prediction.

Alternatively, the 2 -fold difference in lamp power supply may have contributed to the 2 -fold difference in Synechococcus abundance observed using the Olympus $(100 \mathrm{~W})$ and Zeiss $(50 \mathrm{~W})$ epifluorescence microscopes (Table 2). However, this variable was not examined in this study, nor are we aware of this being systematically examined in other published studies.

We have clearly shown that storage mode and duration can significantly influence the accurate enumeration of Synechococcus from natural samples. The question which follows from this result is whether the ACL due to storage may have influenced the interpretation of microbial distributions or dynamics. To address this, we surveyed published reports on Synechococcus distributions and compiled a list of storage mode, duration, wavebands used to excite pigments and the lamp power supply (Table 3 ). Most ( 75\%) of the studies stored samples using the FF method and counted them $<3$ mo after collection. About $10 \%$ of the studies stored samples using other methods and counted samples immediately. Based on our results (Fig. 1, Table 1), it is unlikely that Synechococcus abundances have been underestimated due to storage mode and duration. It is important to note however that $80 \%$ of the studies used blue excitation and $55 \%$ used a $50 \mathrm{~W}$ power supply (Table 3). Although 1 study specifically tested for differences between counts made with blue and green excitation (Booth 1987), we are unaware of studies which systematically examined the effect of power supply on the enumeration of Synechococcus. It is therefore likely that studies using blue excitation and a $50 \mathrm{~W}$ power supply may have underestimated Synechococcus abundance. Consequently, Synechococcus may indeed make a greater contribution to microbial biomass than has previously been reported.

Acknowledgements. We thank P. Matthews for assistance in sample collection and logistic support, $\mathrm{H}$. Chen for advice on statistical analysis and Drs M. R. Anderson, J. D. Pakulski and P. Saunders for comments on a draft of the manuscript. This research was supported by grants to R.B.R. from the Natural Sciences and Engineering Research Council of Canada.

\section{LITERATURE CITED}

Affronti LF, Marshall HG (1993) Diel abundance and productivity patterns of autotrophic picoplankton in the lower Chesapeake Bay. J Plankton Res 15:1-8

Booth BC (1987) The use of autofluorescence for analyzing oceanic phytoplankton communities. Bot Mar 30:101-108

Booth BC (1988) Size classes and major taxonomic groups of phytoplankton at two locations in the subarctic Pacific Ocean in May and August, 1984. Mar Biol 97:275-286

Booth BC, Lewin J, Postel JR (1993) Temporal variation in the structure of autotrophic and heterotrophic communities in the subarctic Pacific. Prog Oceanogr 32:57-99

Burkill PH, Leaky RJG, Owens NJP, Mantoura RFC (1993) Synechococcus and its importance to the microbial foodweb of the northwestern Indian Ocean. Deep-Sea Res 40: $773-782$

Campbell L, Carpenter EJ (1986) Estimating the grazing pressure of heterotrophic nanoplankton on Synechococcus spp. using the seawater dilution and selective inhibitor techniques. Mar Ecol Prog Ser 33:121-129

Campbell L, Iturriaga R (1988) Identification of Synechococcus spp. in the Sargasso Sea by immunofluorescence and fluorescence excitation spectroscopy performed on individual cells. Limnol Oceanogr 33:1196-1201

Caron DA, Pick FR, Lean DRS (1985) Chroococcoid cyanobacteria in Lake Ontario: vertical and seasonal distributions during 1982. J Phycol 21:171-175

Caron DA, Lim EL, Miceli G, Waterbury JB, Valois FW (1991) Grazing and utilization of chroococcoid cyanobacteria and heterotrophic bacteria by protozoa in laboratory cultures and a coastal plankton community. Mar Ecol Prog Ser 76 : 205-217

Chang J, Chung CC, Gong GC (1996) Influences of cyclones on chlorophyll a concentration and Synechococcus abundance in a subtropical western Pacific coastal ecosystem. Mar Ecol Prog Ser 140:199-205

Cho BC, Azam F (1990) Biogeochemical significance of bacterial biomass in the ocean's euphotic zone. Mar Ecol Prog Ser 63:253-259

Crocker KG (1994) Relationships and seasonal distributions of bacterioplankton and phytoplankton in Logy Bay, Newfoundland. Honours thesis, Memorial University of Newfoundland, St. John's, NF

Detmer AE, Bathmann UV (1997) Distribution patterns of autotrophic pico- and nanoplankton and their relative contribution to algal biomass during spring in the Atlantic sector of the Southern Ocean. Deep-Sea Res 44:299-320

Fahnenstiel GL, Carrick HJ (1991) Physiological characteristics and food-web dynamics of Synechococcus in Lake Huron and Michigan. Limnol Oceanogr 36:219-234

Fenchel T (1988) Marine plankton food chains. Annu Rev Ecol Syst 19:19-38

Fessenden RJ, Fessenden JS (1986) Organic chemistry, 3rd edn. Brooks, Monterey, CA

Fuhrman JA, Sleeter TD, Carlson CA, Proctor LM (1989) Dominance of bacterial biomass in the Sargasso Sea and its ecological implications. Mar Ecol Prog Ser 57:207-217

Glover, HE, Campbell L, Prézelin BB (1986) Contribution of Synechococcus spp. to size-fractionated primary productivity in three water masses in the Northwest Atlantic Ocean. Mar Biol 91:193-203

Glover HE, Prézelin BB, Campbell L, Wyman W (1988) Picoand ultraplankton Sargasso Sea communities: variability and comparative distributions of Synechococcus spp. and algae. Mar Ecol Prog Ser 49:127-139

Gundersen K, Bratbak G. Heldal M (1996) Factors influencing 
loss of bacteria in preserved seawater samples. Mar Ecol Prog Ser 137:305-310

Hall JA (1991) Long-term preservation of picophytoplankton for counting by fluorescence microscopy. Br Phycol J 26: $169-174$

Hall JA, Vincent WF (1990) Vertical and horizontal structure in the picoplankton communities of a coastal upwelling system. Mar Biol 106:465-47.

Hasle GR (1978) Identification problems. In: Sournia A (ed) Phytoplankton manual. United Nations Educational Scientific and Cultural Organization, Paris, p 125-128

Herbland A, Le Bouteiller A, Raimbault P (1985) Size structure of phytoplankton biomass in the equatorial Atlantic Ocean. Deep-Sea Res 32:819-836

Hoar WS (1983) General and comparative physiology, 3rd edn. Prentice-Hall, Englewood Cliffs, NJ

Iriarte A, Purdie DA (1994) Size distribution of chlorophyll a biomass and primary production in a temperature estuary (Southampton Water). the contribution of photosynthetic picoplankton. Mar Ecol Prog Ser 115:283-297

Jackson GA, Eldridge PM (1992) Food web analysis of a planktonic system off Southern California. Mar Ecol Prog Ser 30:223-257

Jerlov NG (1976) Marine optics. Elsevier Press, New York

Joint IR (1986) Physiological ecology of picoplankton in various oceanographic provinces. Can Bull Fish Aquat Sci 214:287-309

Karlson B, Nilsson P (1991) Seasonal distribution of picoplanktonic cyanobacteria of Synechococcus type in the eastern Skagerrak. Ophelia 34:171-179

Kirchman DL (1993) Statistical analysis of direct counts of microbial abundance. In: Kemp PF, Sherr BF, Sherr EB, Cole JJ (eds) Handbook of methods in aquatic microbial ecology. Lewis Publishers, Boca Raton, p 117-119

Kirk JTO (1994) Light and photosynthesis in aquatic ecosystems, 2nd edn. Cambridge University Press, New York

Kononen $\mathrm{K}$, Kuparinen J, Mäkelä K, Laanemets J, Pavelson J, Nömmann S (1996) Initiation of cyanobacterial blooms in a frontal region at the entrance to the Gulf of Finland, Baltic Sea. Limnol Oceanogr 41:98-11.2

Krempin DW, Sullivan CW (1981) The seasonal abundance, vertical distribution, and relative microbial biomass of chroococcoid cyanobacteria at a station in southern California coastal waters. Can J Microbiol 27:1341-1344

Kuosa H (1991) Picoplanktonic algae in the northern Baltic Sea: seasonal dynamics and flagellate grazing. Mar Ecol Prog Ser 73:269-276

Kuylenstierna M, Karlson B (1994) Seasonality and composition of pico- and nanoplanktonic cyanobacteria and protists in the Skagerrak. Bot Mar 37:17-33

Landry MR, Haas LW, Fagerness VL (1984) Dynamics of microbial plankton communities: experiments in Kaneohe Bay, Hawaii. Mar Ecol Prog Ser 16:127-133

Li WKW, Dickie PM (1991) Relationship between the number of dividing and nondividing cells of cyunobactnris in North Atlantic picoplankton. J Phycol 27:559-565

Li WKW, Wood AM (1988) Vertical distribution of North Atlantic ultraphytoplankton: analysis by flow cytometry and epifluorescence microscopy. Deep-Sea Res 35 $1615-1638$

Li WKW, Subba Rao DV, Harrison WG, Smith JC, Cullen JJ, Irwin B, Platt T (1983) Autotrophic picoplankton in the tropical ocean. Science 219:292-294

Li WKW, Dickie PM, Irwin BD. Wood AM (1992) Biomass of bacteria, cyanobacteria, prochlorophytes and photosynthetic eukaryotes in the Sargasso Sea. Deep-Sea Res 39 $501-519$
Macisaac EA, Stockner JG (1993) Enumeration of phototrophic picoplankton by autofluorescence microscopy In: Kemp PF, Sherr BF, Sherr EB, Cole JJ (eds) Handbook of methods in aquatic microbial ecology. Lewis Publishers. Boca Raton, p 187-197

Magazzù G, Decembrini F (1995) Primary production, biomass and abundance of phototrophic picoplankton in the Mediterranean Sea: a review. Aquat Microb Ecol 9 $97-104$

Marchant H.J, Davidson AT, Wright SW (1987) The distribution and abundance of chroococcoid cyanobacteria in the Southern Ocean. Proc NIPR Symp Polar Biol 1:1-9

Maugeri TL, Acosta Pomar MLC, Bruni V, Salomone L (1992) Picoplankton and picophytoplankton in the Ligurian Sea and Straits of Messina (Mediterranean Sea). Bot Mar 35 493-502

Miyazono A, Odate T, Maita Y (1992) Seasonal fluctuations of cell density of cyanobacteria and other picophytoplankton in Iwanai Bay, Japan, Hokkaido, Japan. J Oceanogr 48: $257-266$

Mousseau L, Legendre L, Fortier L (1996) Dynamics of sizefractionated phytoplankton and trophic pathways on the Scotian Shelf and at the shelf break, Northwest Atlantic. Aquat Microb Ecol 10:149-163

Murphy LS, Haugen EM (1985) The distribution and abundance of phototrophic picoplankton in the North Atlantic Limnol Oceanogr 30:47-58

Nagata T, Takai K, Kawanobe K, Kim D, Nakazato R, Guselnikova $N$, Bondarenko $N$, Mologawaya O, Kostrnova $T$ Drucker V, Satoh Y, Watanabe Y (1994) Autotrophic picoplankton in southern Lake Baikal: abundance, growth and grazing mortality during summer. J Plankton Res 16 : 945-959

Olson RJ, Chisholm SW, Zettler ER, Armbrust EV (1988) Analysis of Synechococcus pigment types in the sea using single and dual beam flow cytometry. Deep-Sea Res 35 $425-440$

Platt T, Subba Rao DV, Irwin B (1983) Photosynthesis of picoplankton in the oligotrophic ocean. Nature 301: $702-704$

Prézelin BB, Glover HE, Campbell L (1987) Effects of light intensity and nutrient availability on diel patterns of cell metabolism and growth in populations of Synechococcus spp. Mar Biol 95:469-480

Ray RT, Haas LW, Sieracki ME (1989) Autotrophic picoplankton dynamics in a Chesapeake Bay sub-estuary. Mar Ecol Prog Ser 52:273-285

Shapiro LP, Haugen EM (1988) Seasonal distribution and temperature tolerance of Synechococcus in Boothbay Harbor, Maine. Estuar Coast Shelf Sci 26:517-525

Sheldon RW, Rassoulzadegan F, Azam F, Berman T, Bezanson $D S$, Bianchi $M$, Bonin $D$, Hagström $\AA$, Laval-Peuto $M$, Neveux J, Raimbault P, Rivier A, Sherr B, Sherr E, Van Wambeke F, Wikner J, Wood AM, Yentsch CM (1992) Nano-and picoplankton growth and production in the Ray of Villefranche sur Mer (N.W. Mediterranean). Hydrobiologia 241:91-206

Shimada A, Hasegawá T, Umeda I, Kadoya N, Maruyama T (1993) Spatial mesoscale patterns of West Pacific picophy. toplankton as analyzed by flow cytometry: their contribution to subsurface chlorophyll maxima. Mar Biol 115: $209-215$

Søndergaard M, Jensen LM, Ertebjerg G (1991) Picoalgae in Danish coastal waters during summer stratification. Mar Ecol Prog Ser 79:139-149

Stockner JG (1988) Phototrophic picoplankton: an overview from marine and freshwater ecosystems. Limnol Oceanogr 
$33(4 / 2): 765-775$

Stockner JG, Antia NJ (1986) Algal picoplankton from marine and freshwater ecosystems: a multidisciplinary perspective. Can J Fish Aquat Sci 43:2472-2503

Throndsen J (1978) Preservation and storage. In: Sournia A (ed) Phytoplankton manual. United Nations Educational Scientific and Cultural Organization, Paris, p 69-74

Troussellier M. Courties C. Zettelmaier S (1995) Flow cytometric analysis of coastal lagoon bacterioplankton and picophytoplankton: fixation and storage effects. Estuar Coast Shelf Sci 40:621-633

Turley CM (1993) Direct estimates of bacterial numbers in sea-water samples without incurring cell loss due to sample storage. In: Kemp PF, Sherr BF, Sherr EB, Cole JJ (eds) Handbook of methods in aquatic microbial ecology. Lewis Publishers, Boca Raton, p 143-147

Turley CM, Hughes DJ (1992) Effects of storage on direct estimates of bacterial numbers of preserved seawater samples. Deep-Sea Res 39:395-415

Turley CM, Hughes DJ (1994) The effect of storage tempera. ture on the enumeration of epifluorescence-detectable bacterial cells in preserved seawater samples. J Mar Biol Ass UK 74:259-262

Vanucci S, Acosta Pomar MLC, Maugeri TL (1994) Seasonal pattern of phototrophic picoplankton in the eutrophic coastal waters of the Northern Adriatic sea. Bot Mar 37 : $57-66$

Editorial responsibility: William Li, Dartmouth, Nova Scotia, Canada
Vaulot D, Courties D, Partensky F (1989) A simple method to preserve oceanic phytoplankton for flow cytometric analyses. Cytometry 10:629-635

Venrick EL (1978a) Sampling design. In: Sournia A (ed) Phytoplankton manual. United Nations Educational Scientific and Cultural Organization, Paris, p 7-16

Venrick EL (1978b) How many cells to count? In: Sournia A (ed) Phytoplankton manual. United Nations Educational Scientific and Cultural Organization, Paris, p 167-180

Vézina AF, Platt T (1988) Food web dynamics in the ocean. I. Best estimates of flow networks using inverse methods. Mar Ecol Prog Ser 42:269-287

Walker TD, Marchant HJ (1989) The seasonal occurrence of chroococcoid cyanobacteria at an Antarctic coastal site. Polar Biol 9:193-196

Waterbury JB, Watson SW, Guillard RRL, Brand LE (1979) Widespread occurrence of unicellular, marine, planktonic, cyanobacterium. Nature 277:293-294

Wood MA, Horan PK, Muirhead K, Phinney DA, Yentsch CM, Waterbury JB (1985) Discrimination between types of pigments in marine Synechococcus spp. by scanning spectroscopy, epifluorescence microscopy, and flow cytometry. Limnol Oceanogr 30:1303-1315

Wood MA, Phinney DA, Yentsch CM (1998) Water column transparency and the distribution of spectrally distinct forms of phycoerythrin-containing organisms. Mar Ecol Prog Ser 162:25-31

Submitted: March 9, 1998; Accepted: July 22, 1998

Proofs received from author(s): May 27, 1999 